Supplemental information for:

\title{
An irreversible inhibitor to probe the role of Streptococcus pyogenes cysteine protease SpeB in evasion of host complement defenses
}

Jordan L. Woehl" ${ }^{1 \#}$, Seiya Kitamura ${ }^{1 \#}$, Nicholas Dillon ${ }^{3}$, Zhen Han ${ }^{1}$, Landon J. Edgar ${ }^{1}$, Victor Nizet ${ }^{3,4}$, Dennis W. Wolan $^{1,2 *}$

${ }^{1}$ Department of Molecular Medicine, ${ }^{2}$ Department of Integrative Structural and Computational Biology, The Scripps Research Institute, La Jolla, CA 92037.

${ }^{3}$ Division of Host-Microbe Systems \& Therapeutics, Department of Pediatrics, ${ }^{4}$ Skaggs School of Pharmacy and Pharmaceutical Sciences, UC San Diego, La Jolla, CA, USA.

*Corresponding author: wolan@scripps.edu.

\#Equal contribution

\section{Table of Contents}

S1 Detailed synthetic methods and compound characterization.

S4 Table S1. X-ray data collection and structure refinement statistics of SpeB in complex with 2 S.

S5 Figure S1. Specificity of SpeB inhibitors.

S6 Figure S2. $K_{\mathrm{i}}$ determination of compound $1 S$.

S7 Figure S3. Reversibility of covalent SpeB inhibitors 2S-CMK and 2S.

S8 Figure $S 4 . K_{\text {inact }}$ and $K_{\mathrm{i}}$ determination of $2 S$.

S9 Figure S5. Electron density of $2 S$ bound to SpeB.

S10 Figure S6. Labeling of rSpeB and papain by 2S-alkyne and in-gel fluorescence visualization.

S11 Figure S7. Compound 2S-alkyne restores AP-mediated hemolysis of Er, raw values.

S12 Figure S8. Exogenously added SpeB inhibits complement-mediated C3b deposition on WT S. pyogenes cells in a dose-dependent manner.

S13 Figure S9. Toxicity of compounds on Jurkat T cells.

S14 Supporting Information References. 


\section{Detailed synthetic methods and compound characterization}

\section{General}

All reagents and solvents were purchased from commercial suppliers and were used without further purification.

${ }^{1} \mathrm{H}$ and ${ }^{13} \mathrm{C}$ NMR spectra were collected using a Bruker 600,500 , or $400 \mathrm{MHz}$ spectrometer with chemical shifts reported relative to residual deuterated solvent peaks or a tetramethylsilane internal standard. Accurate masses were measured using an an ESI-TOF (HRMS, Agilent MSD) or MSQ Plus mass spectrometer (LRMS, Thermo Scientific). Reactions were monitored on TLC plates (silica gel 60, F254 coating, EMD Millipore, 1057150001), and spots were either monitored under UV light $(254 \mathrm{~mm})$ or stained with phosphomolybdic acid. The same TLC system was used to test purity, and all final products showed a single spot on TLC with both $\mathrm{KMnO}_{4}$ and UV absorbance. The purity of the compounds that were tested in the assay was $>95 \%$ based on ${ }^{1} \mathrm{H}$ NMR and reverse phase HPLC-UV on monitoring absorption at $240 \mathrm{~nm}$. It should be noted that SpeB is susceptible to divalent cations such as $\mathrm{Cu}^{2+}, \mathrm{Zn}^{2+}$; thus, care was taken to ensure that the final products did not contain contaminations of these metals.<smiles>N=CC(=O)C(Cc1cccc([N+](=O)[O-])c1)NC(=O)OCc1ccccc1</smiles>

(S)-2-(((benzyloxy)carbonyl)amino)-3-(3-nitrophenyl)propanoic acid was synthesized previously. ${ }^{1}$ Carboxylic acid was converted into diazoketone using a method previously described. To a stirred solution of (S)-2(((benzyloxy)carbonyl)amino)-3-(3-nitrophenyl)propanoic acid $(500 \mathrm{mg}, 1.45 \mathrm{mmol})$ in DCM at $0{ }^{\circ} \mathrm{C}$ was added dropwise $\mathrm{N}$-methylmorpholine $(154 \mathrm{mg}, 1.53 \mathrm{mmol}, 1.05 \mathrm{eq}$.) and isobutyl chloroformate $(200 \mu \mathrm{L}, 1.53 \mathrm{mmol}$, 1.05 eq.). After $15 \mathrm{~min}$, ethereal diazomethane was generated from Diazald $\circledast$ (931 mg, $4.35 \mathrm{mmol})$ in accordance to procedures outlined in Aldrich Technical Bulletin AL-180 and distilled into stirred solution over the course of 30 minutes. After distillation, the reaction was allowed to warm to r.t. and continue for 1 hour. Glacial acetic acid was added dropwise after being chilled to quench excess diazomethane. One third of the reaction was separated and the solvent was removed in vacuo, dissolved in ethyl acetate and subsequently washed with water, sat. aq. $\mathrm{NaHCO}_{3}$ twice, sat. aq. $\mathrm{NaCl}$, dried over $\mathrm{MgSO}_{4}$, and concentrated in vacuo. Recrystallization from acetone yielded the desired product as a white solid $(45 \mathrm{mg}, 0.12 \mathrm{mmol}, 25 \%)$. ${ }^{1} \mathrm{H}$ NMR $\left(600 \mathrm{MHz}\right.$, DMSO- $\left.d_{6}\right) \delta 8.22(\mathrm{t}$, $J=2.0 \mathrm{~Hz}, 1 \mathrm{H}), 8.10(\mathrm{dd}, J=8.0,2.4 \mathrm{~Hz}, 1 \mathrm{H}), 7.87(\mathrm{~d}, J=8.8 \mathrm{~Hz}, 1 \mathrm{H}), 7.76(\mathrm{~d}, J=7.6 \mathrm{~Hz}, 1 \mathrm{H}), 7.58(\mathrm{t}, J=7.9$ $\mathrm{Hz}, 1 \mathrm{H}), 7.34-7.26(\mathrm{~m}, 3 \mathrm{H}), 7.21-7.16(\mathrm{~m}, 2 \mathrm{H}), 6.28$ (broad s, $1 \mathrm{H}), 4.96(\mathrm{~d}, J=12.7 \mathrm{~Hz}, 1 \mathrm{H}), 4.92(\mathrm{~d}, J=12.7$ $\mathrm{Hz}, 1 \mathrm{H}), 4.38-4.32(\mathrm{~m}, 1 \mathrm{H}), 3.20(\mathrm{dd}, J=13.8,4.2 \mathrm{~Hz}, 1 \mathrm{H}), 2.85(\mathrm{dd}, J=13.8,11.1 \mathrm{~Hz}, 1 \mathrm{H}) .{ }^{13} \mathrm{C}$ NMR $(151$ $\mathrm{MHz}$, DMSO) $\delta$ 193.9, 155.9, 147.6, 140.2, 136.8, 136.3, 129.6, 128.3, 127.8, 127.4, 124.0, 121.5, 65.4, 59.3, 53.4, 35.7. HRMS (+) calcd for $(\mathrm{M}+\mathrm{Na})^{+}$391.1013. Found 391.1018. Purity (HPLC-UV): 98\%.

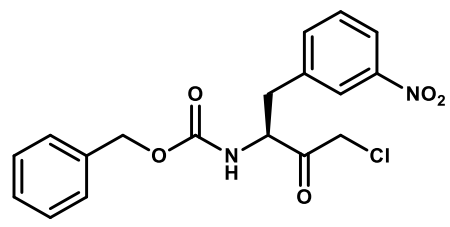

Two third of the reaction above was separated and to this mixture was added cocn. aq. $\mathrm{HCl}$. dropwise until the conversion completed. The solvent was removed in vacuo, dissolved in ethyl acetate and subsequently washed with water, sat. aq. $\mathrm{NaHCO}_{3}$ twice, sat. aq. $\mathrm{NaCl}$, dried over $\mathrm{MgSO}_{4}$, and concentrated in vacuo. Recrystallization from acetone yielded the desired product as White solid (160 mg, $0.43 \mathrm{mmol}, 44 \%)$. ${ }^{1} \mathrm{H}$ NMR $\left(600 \mathrm{MHz}, \mathrm{DMSO}-d_{6}\right) \delta 8.20(\mathrm{t}, J=2.0 \mathrm{~Hz}, 1 \mathrm{H}), 8.10$ (ddd, $\left.J=8.2,2.4,1.0 \mathrm{~Hz}, 1 \mathrm{H}\right), 7.89(\mathrm{~d}, J=8.4 \mathrm{~Hz}, 1 \mathrm{H})$, $7.73(\mathrm{dt}, J=7.6,1.4 \mathrm{~Hz}, 1 \mathrm{H}), 7.58(\mathrm{t}, J=7.9 \mathrm{~Hz}, 1 \mathrm{H}), 7.35-7.26(\mathrm{~m}, 3 \mathrm{H}), 7.23-7.18(\mathrm{~m}, 2 \mathrm{H}), 4.99-4.90(\mathrm{~m}$, $2 \mathrm{H}), 4.76(\mathrm{~d}, J=16.9 \mathrm{~Hz}, 1 \mathrm{H}), 4.71(\mathrm{~d}, J=16.9 \mathrm{~Hz}, 1 \mathrm{H}), 4.56(\mathrm{ddd}, J=10.8,8.4,4.1 \mathrm{~Hz}, 1 \mathrm{H}), 3.30$ (dd, $J=13.8$, $4.1 \mathrm{~Hz}, 1 \mathrm{H}), 2.85$ (dd, $J=13.9,10.8 \mathrm{~Hz}, 1 \mathrm{H}) .{ }^{13} \mathrm{C}$ NMR $(151 \mathrm{MHz}, \mathrm{DMSO}) \delta 200.3,156.0,147.6,140.0,136.7$, 136.3, 129.6, 128.3, 127.8, 127.5, 124.0, 121.6, 65.6, 59.1, 47.7, 34.4. HRMS (+) calcd for $(\mathrm{M}+\mathrm{H})^{+} 377.0899$. Found 377.0909. Purity (HPLC-UV): $>99 \%$. 
<smiles>C#Cc1cccc(COC(=O)NC(Cc2cccc([N+](=O)[O-])c2)C(=O)O)c1</smiles>

(3-ethynylphenyl)methanol was synthesized using the method described previously., 3 Spectral data matched with reported values. ${ }^{2}$ Target carbamate was synthesized from the (3-ethynylphenyl)methanol and (S)-2-amino3-(3-nitrophenyl)propanoic acid using the method ${ }^{1}$ described previously $\left(1.26 \mathrm{~g}(3.42 \mathrm{mmol}, 94 \%)\right.$. ${ }^{1} \mathrm{H}$ NMR (600 $\mathrm{MHz}$, Chloroform-d) $\delta 8.10(\mathrm{~s}, 1 \mathrm{H}), 7.54-7.39(\mathrm{~m}, 5 \mathrm{H}), 7.31(\mathrm{~d}, J=6.8 \mathrm{~Hz}, 3 \mathrm{H}), 5.37(\mathrm{~d}, J=7.8 \mathrm{~Hz}, 1 \mathrm{H}), 5.09$ $-5.01(\mathrm{~m}, 2 \mathrm{H}), 4.75-4.70(\mathrm{~m}, 1 \mathrm{H}), 3.36(\mathrm{dd}, J=14.0,5.5 \mathrm{~Hz}, 1 \mathrm{H}), 3.19(\mathrm{dd}, J=14.2,6.4 \mathrm{~Hz}, 1 \mathrm{H}), 3.09-3.07(\mathrm{~m}$, $1 \mathrm{H}), 3.02-2.96(\mathrm{~m}, 1 \mathrm{H}) .{ }^{13} \mathrm{C}$ NMR $(151 \mathrm{MHz}$, Chloroform-d) $\delta 173.50,155.07,147.81,137.42,135.86,135.23$, $131.49,131.12,129.09,129.04,126.91,123.81,121.99,121.87,82.73,77.16,66.08,53.92,30.48$. LRMS (+) calcd for $(\mathrm{M}+\mathrm{H})^{+}$369.1. Found 369.2.

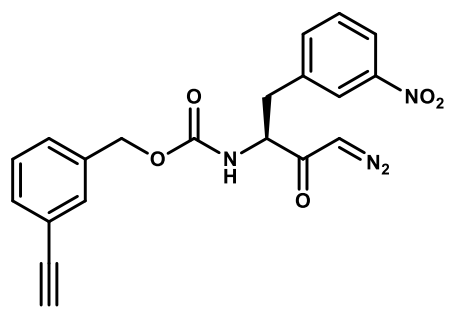

Target molecule was synthesized using the method described for benzyl (S)-(4-diazo-1-(3-nitrophenyl)-3oxobutan-2-yl)carbamate (300 mg $(0.76 \mathrm{mmol}, 50 \%)) .{ }^{1} \mathrm{H}$ NMR $\left(600 \mathrm{MHz}\right.$, DMSO- $\left.d_{6}\right) \delta 8.22(\mathrm{~s}, 1 \mathrm{H}), 8.09(\mathrm{~d}, \mathrm{~J}=$ $8.4 \mathrm{~Hz}, 1 \mathrm{H}), 7.91(\mathrm{~d}, J=8.9 \mathrm{~Hz}, 1 \mathrm{H}), 7.76(\mathrm{~d}, J=7.8 \mathrm{~Hz}, 1 \mathrm{H}), 7.57(\mathrm{t}, J=7.9 \mathrm{~Hz}, 1 \mathrm{H}), 7.42-7.26(\mathrm{~m}, 4 \mathrm{H}), 7.24$ $(\mathrm{d}, J=7.8 \mathrm{~Hz}, 1 \mathrm{H}), 6.29(\mathrm{~s}, 1 \mathrm{H}), 4.95(\mathrm{~s}, 2 \mathrm{H}), 4.34(\mathrm{~s}, 1 \mathrm{H}), 4.19(\mathrm{~d}, J=7.0 \mathrm{~Hz}, 2 \mathrm{H}), 3.20$ (dd, $J=13.9,4.2 \mathrm{~Hz}$, $1 \mathrm{H}), 2.86(\mathrm{dd}, J=13.8,11.1 \mathrm{~Hz}, 1 \mathrm{H}) .{ }^{13} \mathrm{C}$ NMR (151 MHz, DMSO) $\delta$ 193.8, 155.8, 147.6, 140.2, 137.5, 136.2, 131.0, 130.5, 129.5, 128.7, 127.9, 124.0, 121.7, 121.5, 83.1, 80.9, 64.8, 59.3, 53.4, 35.7. HRMS (+) calcd for $(\mathrm{M}+\mathrm{Na})^{+}$415.1013. Found 415.1018. Purity (HPLC-UV): $96 \%$. 
Table S1. X-ray crystallography data collection and refinement statistics.

\begin{tabular}{|c|c|}
\hline PDB ID & $6 \mathrm{UKD}$ \\
\hline Wavelength $(\AA)$ & 0.97946 \\
\hline Space group & $\mathrm{P} 22{ }_{12} 1$ \\
\hline Unit Cell Parameters $(a, b, c)(\AA)$ & $37.27,50.40,114.50$ \\
\hline \multicolumn{2}{|l|}{ Data Processing } \\
\hline Resolution range $(\AA)$ (outer shell) & $37.27-1.58(1.66-1.59)$ \\
\hline Unique reflections & $29,409(2,644)$ \\
\hline Completeness (\%) & $98.3(90.0)$ \\
\hline Redundancy & $5.8(3.5)$ \\
\hline $\mathrm{R}_{\text {meas }}(\%)^{\mathrm{a}}$ & $11.5(47.7)$ \\
\hline$R_{\text {merge }}(\%)^{b}$ & $8.7(40.4)$ \\
\hline Rp.i.m. $(\%)^{\mathrm{c}}$ & $4.5(22.2)$ \\
\hline Average $I / \sigma(I)$ & $17.4(2.2)$ \\
\hline Wilson $B\left(\AA^{2}\right)$ & 14.0 \\
\hline \multicolumn{2}{|l|}{ Refinement } \\
\hline Resolution range $(\AA)$ & $37.27-1.59(1.65-1.59)$ \\
\hline No. reflections (test set) ${ }^{d}$ & $29,406(1,048)$ \\
\hline $\mathrm{R}_{\text {cryst }}(\%)^{\mathrm{e}}$ & $15.3(20.7)$ \\
\hline $\mathrm{R}_{\text {free }}(\%)$ & $18.9(25.7)$ \\
\hline Protein atoms / waters / ligands & $2,000 / 317 / 33$ \\
\hline CV coordinate error $(\AA)^{f}$ & 0.15 \\
\hline Rmsd bonds $(\AA) /$ angles $\left({ }^{\circ}\right)$ & $0.009 / 1.01$ \\
\hline B-values protein/waters/ligands $\left(\AA^{2}\right)$ & 13.4 / 27.4 / 25.2 \\
\hline \multicolumn{2}{|l|}{ Ramachandran Statistics (\%) } \\
\hline Most favored & 98.4 \\
\hline Additional allowed & 1.6 \\
\hline Generously allowed & 0.0 \\
\hline
\end{tabular}

${ }^{a} R_{\text {meas }}=/ \Sigma_{\text {hkl }} \Sigma_{i} l_{i(h k l)}$, where $l_{i(h k l)}$ are the observed intensities, $<l_{(h k l)}>$ are the average intensities and $N$ is the multiplicity of reflection hkl. ${ }^{b} R_{\text {merge }}=\Sigma_{\mathrm{hk} \mid} \Sigma_{\mathrm{i}} \mathrm{l}_{\mathrm{i}(\mathrm{hkl})}-<\mathrm{l}_{(\mathrm{hkl})}>\mid / \Sigma_{\mathrm{hkl}} \Sigma_{\mathrm{i}} \mathrm{l}_{\mathrm{i}(\mathrm{hkl})}$ where $\mathrm{l}_{\mathrm{i}(\mathrm{hkl})}$ is the $\mathrm{i}^{\text {th }}$ measurement of reflection $\mathrm{h}$ and $\left\langle\mathrm{l}_{(\mathrm{hkl})}\right\rangle$ is the average measurement value. ${ }^{c} R_{\text {p.i.m. }}$ (precision-indicating $\left.R_{\text {merge }}\right)=\Sigma_{h k l}\left[1 /\left(N_{h k l}-1\right)\right]^{1 / 2} \Sigma_{i l} l_{i(h k l)}-$ $\left\langle\mathrm{l}_{(\mathrm{hkl})}\right\rangle \mid / \Sigma_{\mathrm{hkl}} \Sigma_{\mathrm{i}} \mathrm{l}_{(\mathrm{hkl}) .}{ }^{\mathrm{d}}$ Reflections with I $>0$ were used for refinement. ${ }^{4} \mathrm{e}_{\text {cryst }}=\Sigma_{\mathrm{h}}|| \mathrm{F}_{\text {obs }}|-| \mathrm{F}_{\text {calc }}|| / \Sigma \mid \mathrm{F}_{\text {obs }}$, where $\mathrm{F}_{\text {obs }}$ and $F_{\text {calc }}$ are the calculated and observed structure factor amplitudes, respectively. $R_{\text {free }}$ is $R_{\text {cryst }}$ with $5.0 \%$ test set structure factors. ${ }^{\mathrm{f}}$ Cross-validated (CV) Luzzati coordinate errors. 


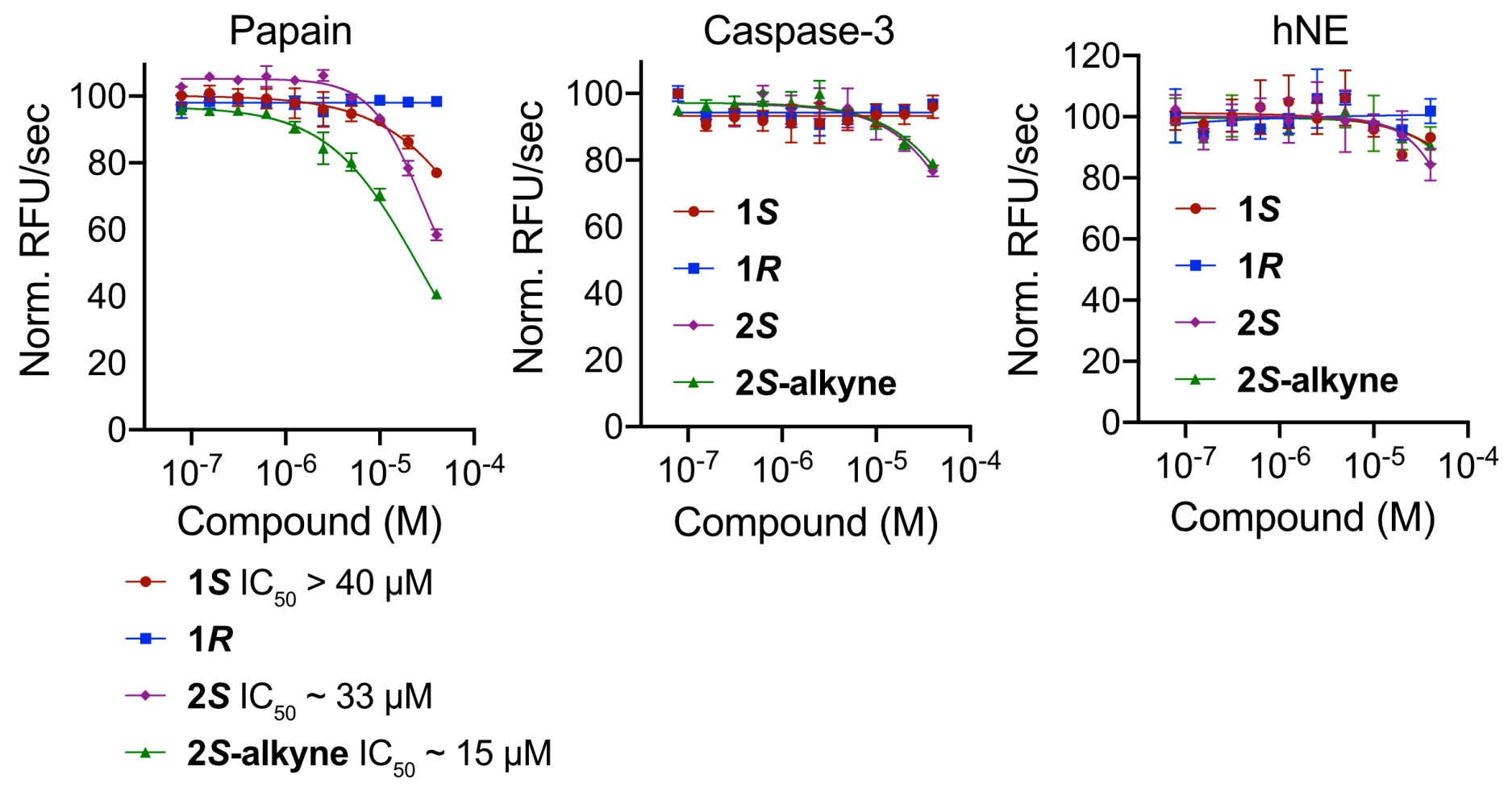

Figure S1. Specificity of SpeB inhibitors. Dose-response curves of each compound against papain (Ac-AlKAMC), caspase-3 (Ac-DEVD-AMAC), or hNE (Ac-AAPV-AMC). Each compound was assessed over a 2-fold logarithmic dilution series. $I_{50}$ values were measured based on 10-min incubation and are shown in mean \pm SD $(n \geq 3)$. 


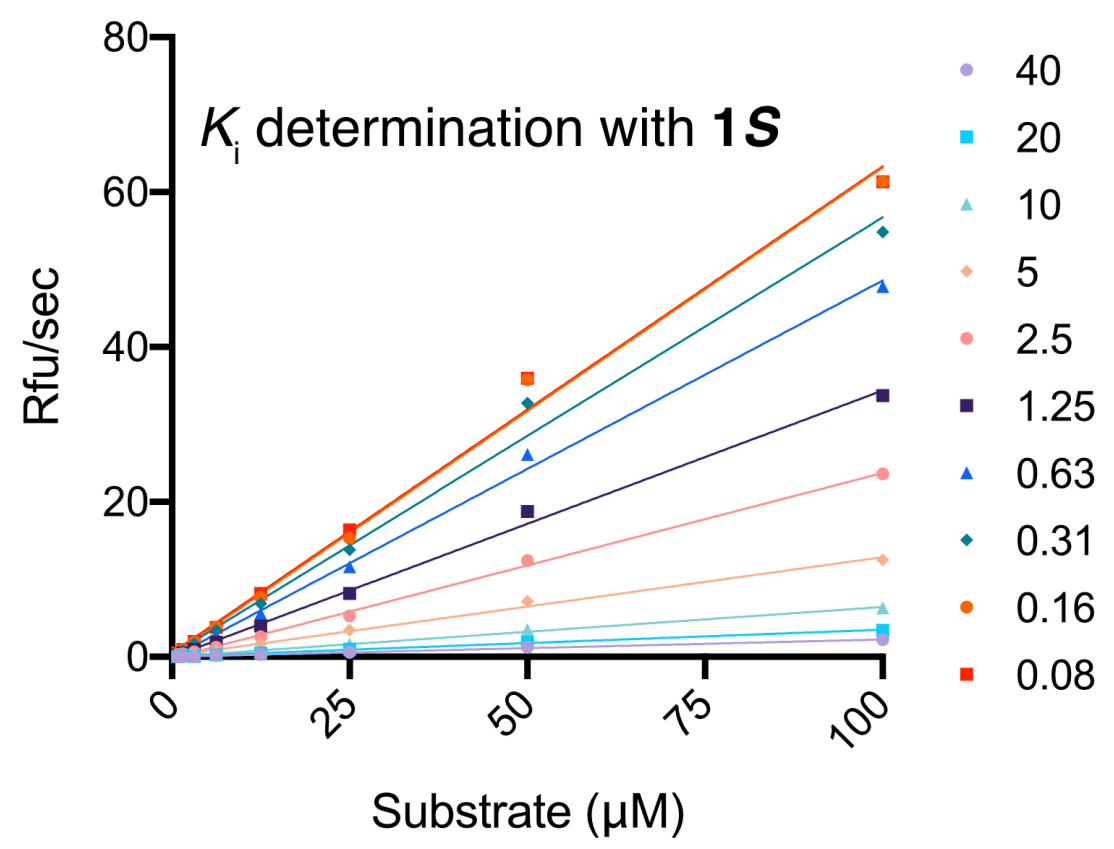

Figure S2. $K_{\mathrm{i}}$ determination of compound 1S. Dose-response curves of $1 S$ against $r S p e B$ with changes in substrate (Ac-AIK-AMC) concentration are shown. 
<smiles>CC(C)CS(C)(C)C(=O)CCl</smiles><smiles>O=C(N[C@@H](Cc1cccc([N+](=O)[O-])c1)C(=O)N=[W])OCc1ccccc1</smiles>
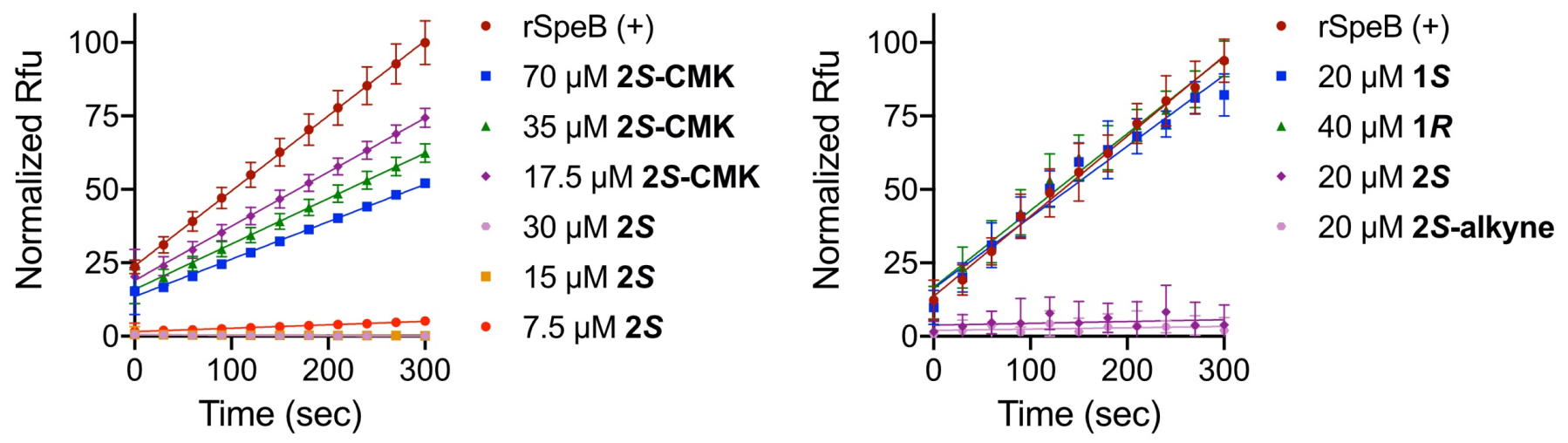

Figure S3. Reversibility of SpeB inhibitors. Compounds 2S-CMK $\left(\mathrm{IC}_{50}=\sim 6.7 \mu \mathrm{M}\right)$ and $2 \mathrm{~S}\left(\mathrm{IC}_{50}=\sim 1.9 \mu \mathrm{M}\right)$ incubated for 30 min at a concentration $\sim 10$-fold above the $\mathrm{IC}_{50}$ with $\mathrm{rSpeB}(2 \mu \mathrm{M})$ at 100 -fold the activity assay concentration. Following incubation, reaction mixture diluted 1:100 in assay buffer and substrate added. Loss of SpeB inhibition over time is shown with $2 S-C M K$, but not with $2 S$, suggesting $2 S$ is an irreversible inhibitor. Similar assay run with compounds $1 S, 1 R, 2 S$, and $2 S$-alkyne shows $2 S / 2 S$-alkyne are the only irreversible inhibitors. 

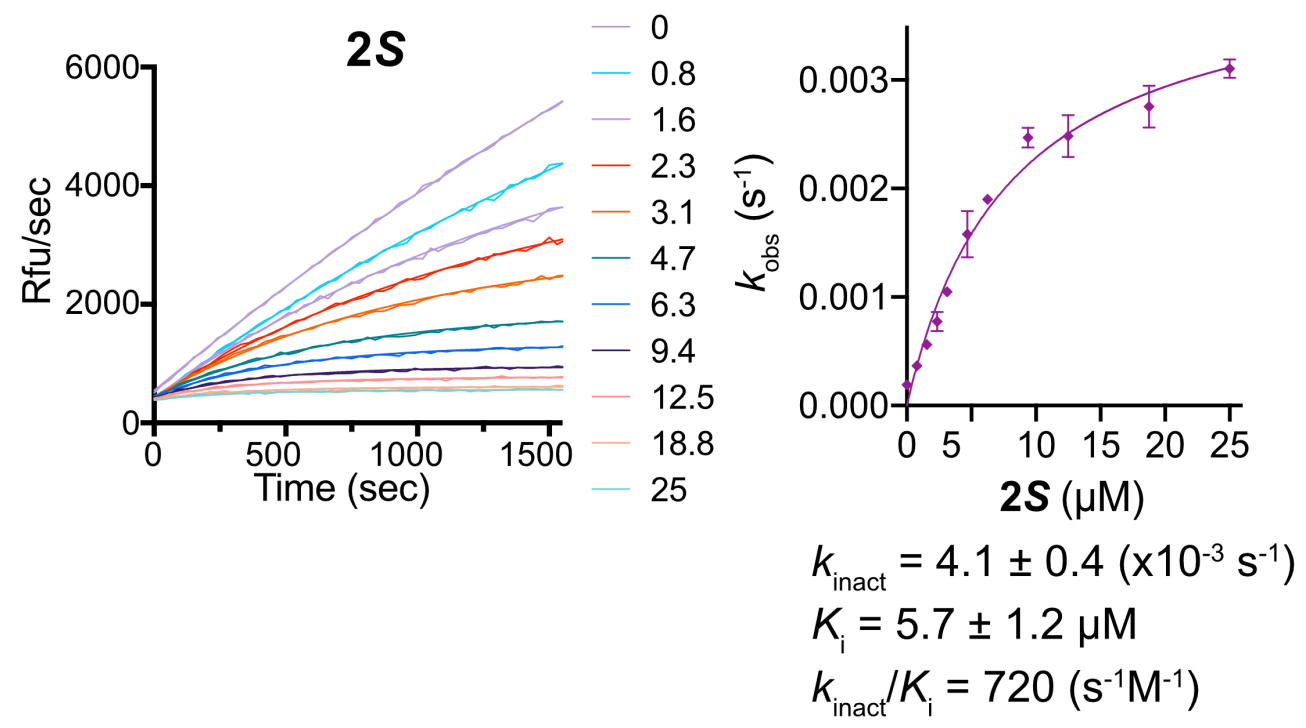

Figure S4. $k_{\text {inact }}$ and $K_{\mathrm{i}}$ determination of $2 \mathrm{~S}$. Dose-response curves of each compound against rSpeB with a constant substrate (Ac-AIK-AMC) concentration of $100 \mu \mathrm{M} . K_{i}$ and $k_{\text {inact }}$ values were determined using the model described by Kuzmič et al. ${ }^{5}$ 

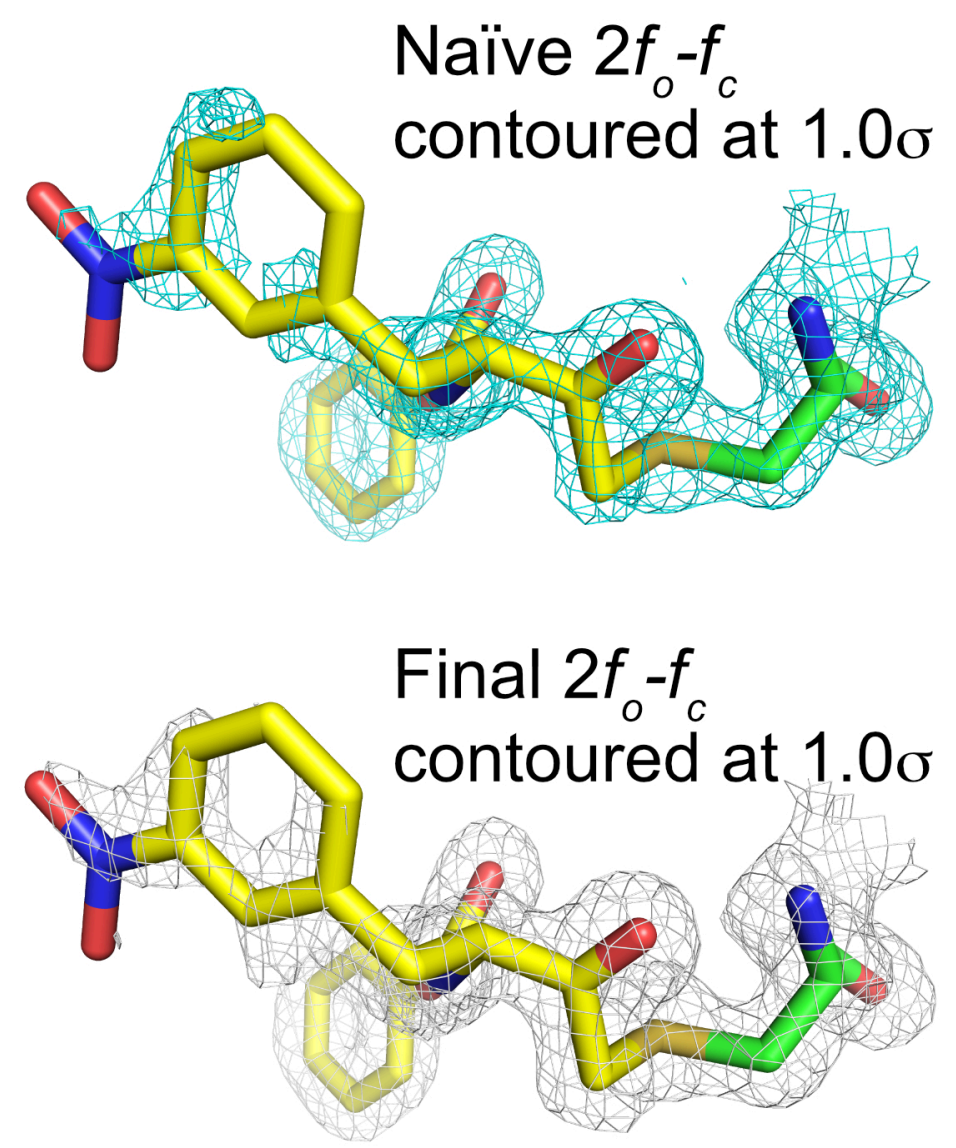

Figure S5. Electron density of $2 S$ bound to SpeB. Naïve $2 f_{o}-f_{c}$ map contoured at $1.0 \sigma$ and final $2 f_{o}-f_{c}$ map contoured at $1.0 \sigma$ clearly delineates the binding of $2 S$ to $C 192$ and orientation of the compound in the active site of SpeB. Residues of Cys192 (green) and $2 S$ shown as a stick model with yellow carbon, red oxygen, blue nitrogen, and mustard sulfur. 

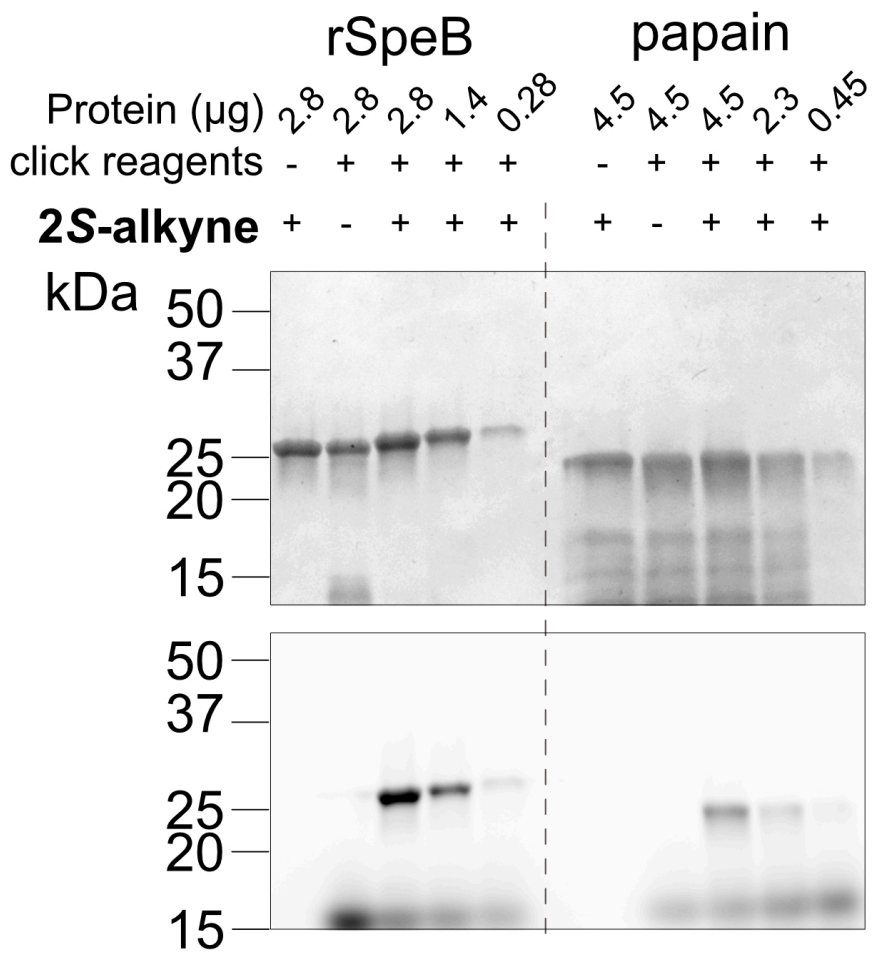

Figure S6. In situ labeling of rSpeB and papain with 2S-alkyne. Recombinant SpeB (2.8 to $0.28 \mu \mathrm{g})$ and papain $(4.5$ to $0.45 \mu \mathrm{g})$ were labeled with $2 S$-alkyne with Coomassie stain (top) and in-gel fluorescence (bottom). Recombinant SpeB and papain were incubated in $40 \mu \mathrm{L}$ with $100 \mu \mathrm{M} 2$ S-alkyne or DMSO (control) at $25^{\circ} \mathrm{C}$ for $30 \mathrm{~min}$. Click cocktail was added into the protein-probe mixture with final concentrations of $100 \mu \mathrm{M} \mathrm{CuSO} 4,500$ $\mu \mathrm{M}$ BTTAA (Click Chemistry Tools), $5 \mathrm{mM}$ sodium ascorbate, and $100 \mu \mathrm{M}$ AFDye 647 Azide (Click Chemistry Tools). The reaction mixtures were incubated at $25{ }^{\circ} \mathrm{C}$ for $1 \mathrm{~h} .10 \mu \mathrm{L}$ was removed and combined with $3.3 \mu \mathrm{L}$ SDS-PAGE loading dye. Samples were resolved on a 4-20\% SDS-PAGE gradient gel, destained, and imaged using a Chemidoc MP Imaging System (Bio-Rad). 


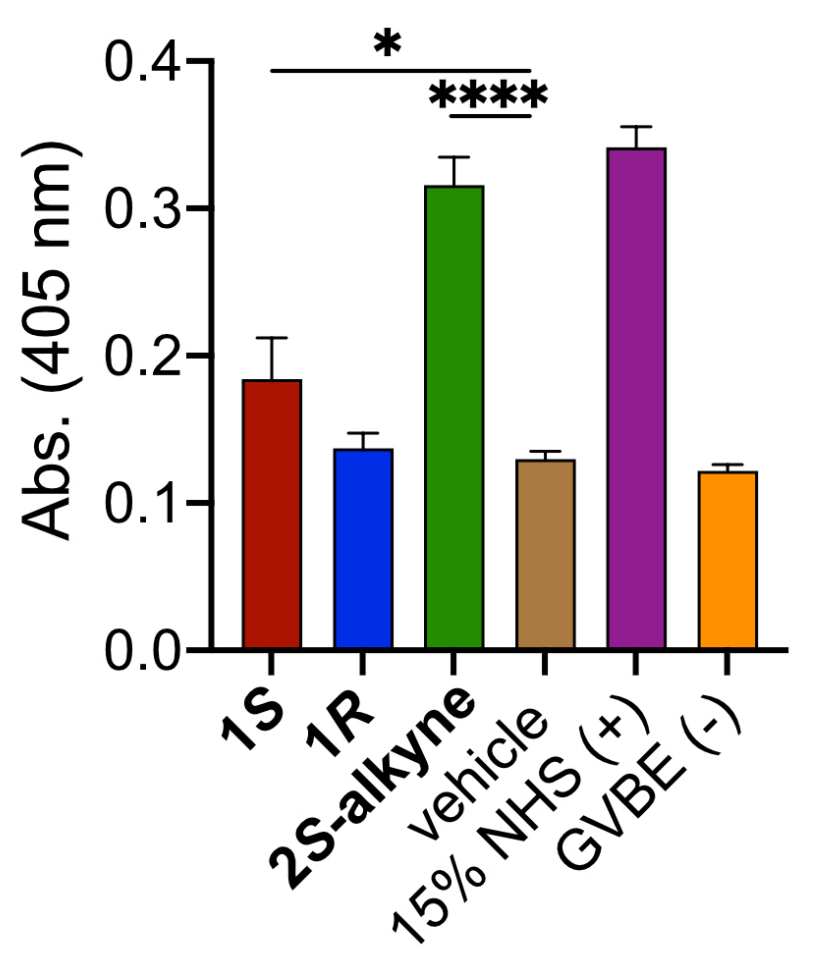

Figure S7. Compound 2S-alkyne restores AP-mediated hemolysis of Er, raw values. The ability of the compounds to restore AP-mediated hemolysis of Er was assessed using a fixed concentration of rSpeB (5 $\mu \mathrm{M})$, NHS [15\% (v/v)], and compound $(20 \mu \mathrm{M})$. Values represent absorbance (Abs.) at $405 \mathrm{~nm}$ with no normalization to controls. 15\% (v/v) NHS alone represents the positive control; GHBS ${ }^{\circ}+$ EDTA (GVBE) represents the negative control from the ability of EDTA to knockout alternative pathway metal-dependent activation. Data are shown as mean $\pm \mathrm{SD}(\mathrm{n} \geq 3) .{ }^{*} p$-value $=0.024,{ }^{* * *}=<0.0001$ using a one-way ANOVA test. 

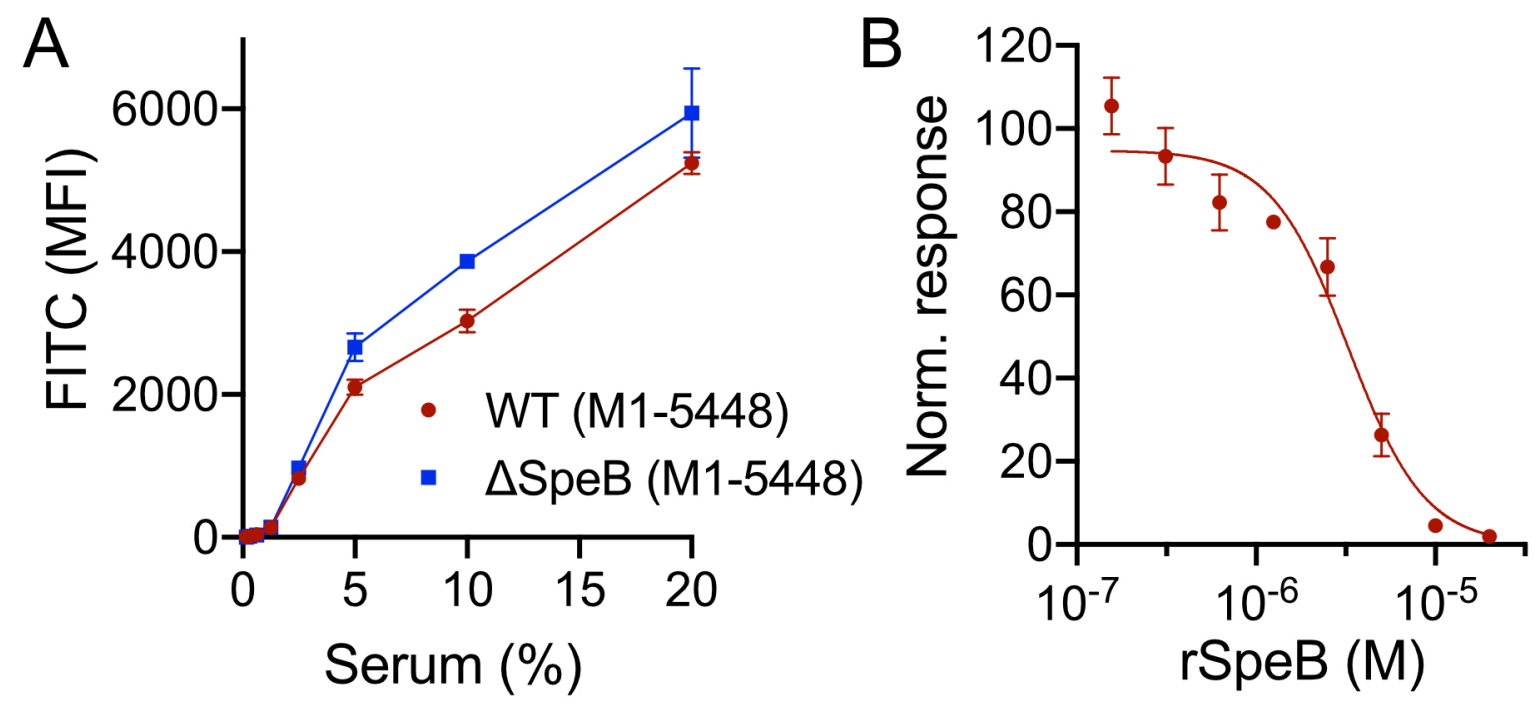

Figure S8. Exogenously added SpeB inhibits complement-mediated C3b deposition on WT and $\Delta s p e B S$. pyogenes cells in a dose-dependent manner. $S$. pyogenes was grown overnight, diluted in assay buffer, and incubated with NHS in a dose-dependent manner [0.2 to $25 \%(\mathrm{v} / \mathrm{v})]$ and C3b deposition was analyzed using a FITC-conjugated anti-C3b antibody. (A) C3b deposition is increased in correlation to NHS (\%). (B) At a single percentage of NHS (10\%), exogenous SpeB was added in a dose-dependent manner to NHS/WT bacteria and C3b deposition was analyzed. Inhibition of C3b deposition by SpeB was normalized to 10\% NHS (100\% MFI) and $0 \% \mathrm{NHS}(0 \% \mathrm{MFI})$ controls. Values are represented as MFI and are shown as mean $\pm \mathrm{SD}(n \geq 3)$. 


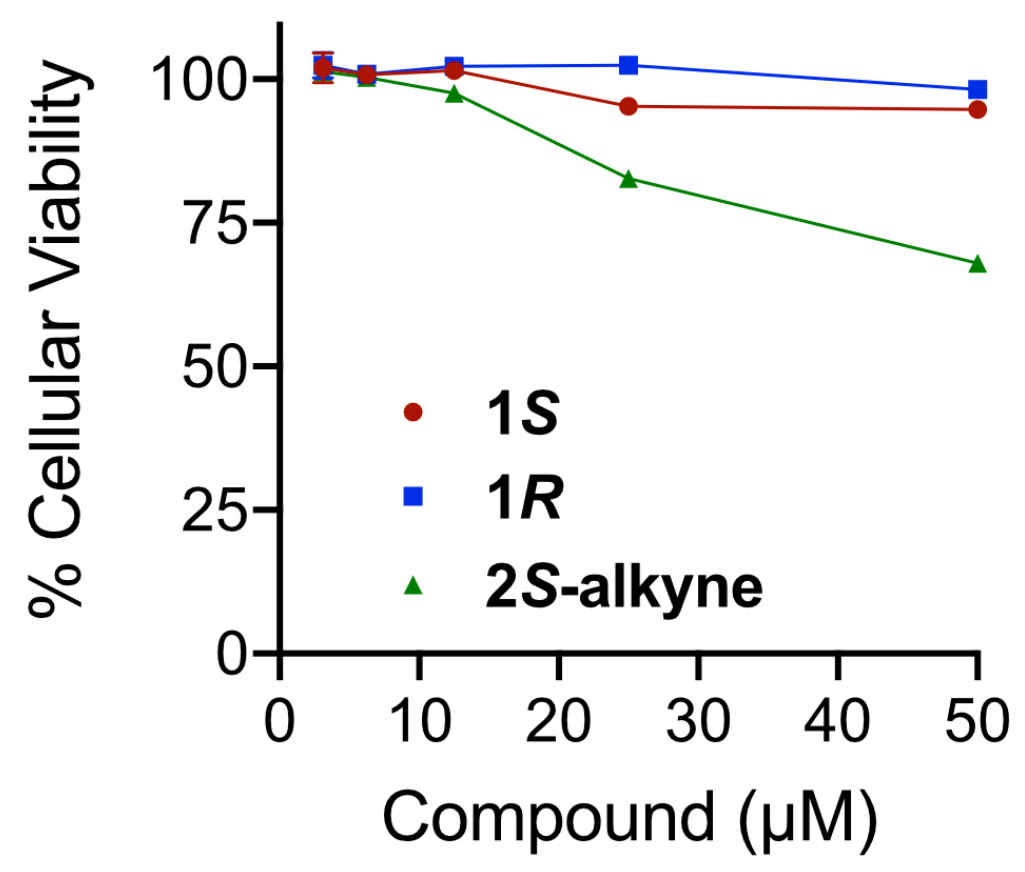

Figure S9. Toxicity of compounds on Jurkat T cells. Cells were treated with increasing concentrations of SpeB inhibitors or DMSO vehicle for $3 \mathrm{~h}$ and cellular viability was measured using CellTiter-Glo ${ }^{\circledR}$. Each data point is shown as mean $\pm \operatorname{SD}(n \geq 3)$. 


\section{Supplementary information references}

1. Kitamura, S.; Zheng, Q.; Woehl, J. L.; Solania, A.; Chen, E.; Dillon, N.; Hull, M.; Kotaniguchi, M.; Kitamura, S.; Nizet, V.; Sharpless, K. B.; Wolan, D. W., SuFEx-enabled high-throughput medicinal chemistry. J. Am. Chem. Soc. 2020, online. doi: 10.1021/jacs.9b13652.

2. Zhang, Q.; Takacs, J. M., Click-connected ligand scaffolds: macrocyclic chelates for asymmetric hydrogenation. Org. Lett. 2008, 10 (4), 545-8.

3. Kitamura, S.; Hvorecny, K. L.; Niu, J.; Hammock, B. D.; Madden, D. R.; Morisseau, C., Rational design of potent and selective inhibitors of an epoxide hydrolase virulence factor from Pseudomonas aeruginosa. J. Med. Chem. 2016, 59 (10), 4790-9.

4. Emsley, P.; Lohkamp, B.; Scott, W. G.; Cowtan, K., Features and development of Coot. Acta Crystallogr. D 2010, 66, 486-501.

5. Kuzmič, P.; Solowiej, J.; Murray, B. W., An algebraic model for the kinetics of covalent enzyme inhibition at low substrate concentrations. Anal. Biochem. 2015, 484, 82-90. 